Legislative advocacy for high quality leadership preparation: Perspectives and implications for teaching and learning educational leadership

By: Katherine Cumings Mansfield and Bradley W. Carpenter

Mansfield, K.C., \& Carpenter, B. (2008). Legislative advocacy for high quality leadership preparation: Perspectives and implications for teaching and learning educational leadership. Journal of Research on Leadership Education, 3(2), 1-8. https://doi.org/10.1177/194277510800300203

$* * *$ (C) 2008. Reprinted with permission. No further reproduction is authorized without written permission from SAGE. This version of the document is not the version of record. Figures and/or pictures may be missing from this format of the document. ***

\begin{abstract}
:
This article interrogates the value of leadership preparation programs connecting academic and political spheres as endorsed in the 2008 revised ISLLC Standards. Specifically, a number of exemplar teaching and learning practices are shared that led to the planning and implementation of legislative advocacy projects for educational leadership professors and students in Washington, DC. Major findings include that although many educators are not adequately prepared nor encouraged to participate in policy making at the state or national levels, purposeful efforts to engage educators in legislative advocacy projects results in positive outcomes for professors, students, and policymakers alike.
\end{abstract}

Keywords: legislative advocacy | leadership | higher education | University Council for Educational Administration (UCEA)

Article:

\title{
Introduction
}

The University Council for Educational Administration (UCEA), in an effort to redirect the scholarly focus on the importance of leadership preparation, challenged its members to probe and interrogate a variety of difficulties faced by today's public school leaders from across the United States. This challenge, as set forth by Dr. Michelle Young and the UCEA leadership team, helped inspire a fresh body of scholarly work re-examining the efficacy of educational leadership preparation programs and the need to connect academic and political spheres. Dr. Young extended this challenge beyond her role as Executive Director for UCEA to her own classroom offerings. This article shares a number of the exemplar teaching and learning practices we experienced as doctoral students in Dr. Young's class as well as the subsequent planning and implementation of legislative advocacy projects. It is our hope that dissemination of our experiences will inform the field as to the positive effects of best practices in teaching and learning in educational leadership programs as well as highlight the consequences of utilizing Interstate School Leaders Licensure Consortium (ISLLC) Standards to bolster attempts to 
produce politically aware and active educational leaders. Optimistically, we hope to stimulate other professors and students to attempt comparable action projects.

First, we provide political context and elaborate on the features of high quality leadership preparation programs. We then describe the unique pedagogical procedures and activities that led to educational leadership doctoral students planning an actual "Day on the Hill" event in Washington, DC. Thereafter, we describe the realized "Day on the Hill" event with emphasis on ways the event served as professional development for participating professors. We then conclude with important insights resulting from the project, as well as future implications for educational leadership students and professionals.

\section{Political Context}

Today's educational environment of high-stakes accountability results in an increasing number of public schools deemed unacceptable according to state and federal educational standards. This public proclamation of failure serves as fodder for the increasingly large number of citizens expressing grave concerns about the perceived inability of schools to provide an adequate educational experience. Although there are extant scholars claiming the intense focus on accountability is in fact the impetus behind innovative reform efforts, there are an equal number of scholars passionately arguing that the heightened pressures placed upon public schools create a series of destructive inputs and outputs that negatively impact students, teachers, administrators, and public school communities.

One of the more disturbing trends explored by scholars who question today's focus on accountability is the astonishing rate of principal turnover. Statistics available from the state of Texas reveal principal turnover is highest at the secondary level at 61 percent in the first three years and 71 percent after five years of service (Fuller, Orr, \& Young, 2008). Moreover, in schools with more than half of the students characterized as economically disadvantaged, the turnover rate is 79 and 81 percent for middle school and high school principals, respectively (Fuller, Orr, \& Young, 2008). While the turnover rates are lowest in elementary schools, principal retention is decelerating fastest at this level (Fuller, Orr, \& Young, 2008).

These figures suggest there may be significant numbers of principals who find themselves in the unenviable position of scapegoat. Today, principals are simultaneously enduring an increasingly prescriptive policy environment, while also facing greater public scrutiny for what the state or federal government determines as unacceptable student achievement outcomes.

\section{Focus on Leadership Preparation}

The assumptive failure of public schools, the concurrent scrutiny of educational leadership, and the alarming rates of principal turnover have renewed scholarly efforts to investigate the quality of educational leadership preparation programs. There are numerous assumptions explaining the current flight of principals. One common assumption suggests principals are simply removed due to their inability to move their school towards acceptable levels of student achievement. If the relationship between principal leadership and student achievement is significant, academia has a 
responsibility to address exactly how university preparation programs should evolve in order to better prepare educational leaders for success in today's heightened accountability environment.

Unfortunately, research interrogating the quality and effectiveness of educational leadership preparation receives inadequate attention by the scholarly community. Even after the politically charged diatribe against the effectiveness of public schools as provided by Nation at-Risk (NAR), educational research often lacks a specific focus on how school leaders are prepared; instead, research efforts are often hyper-focused on the overall performance of schools, the credibility of teacher training institutions, and the qualifications of its teachers (Peterson \& Finn, 1985). However, there are individuals and organizations who seek to address this chasm in research. One example lies in UCEA's recent efforts.

Features of High-quality Leadership Programs

Recent research efforts target specific program characteristics that more effectively prepare educational leaders and produce a highly skilled set of graduate outcomes (Jackson \& Kelly, 2002; Davis, Darling-Hammond, Meyerson, \& LaPointe, 2005; USDOE, 2005). General program characteristics include: rigorous student recruitment and selection; appropriate and adequate staffing and other resources, and purposefully selected knowledge and skills linking to vital values and beliefs. The characteristics found within this general core provide the focus for specific pedagogy and curriculum, resulting in superior student learning and actual practice in the field (Darling-Hammond, LaPointe, Meyerson, Orr, \& Cohen, 2007; Orr, 2007; Orr \& Orphanos, 2007). Table 1, adapted from Young, Fuller, Brewer, Carpenter, and Mansfield (2007), synthesizes specific features of high quality leadership preparation programs found in the literature:

Table 1: Specific features of high quality leadership preparation programs Adapted from: Young, Fuller, Brewer, Carpenter, and Mansfield (2007)

Rigorous selection processes that preference women and racial minorities; Cohort structures that foster collaboration and support;

Research-based content that is focused on instruction, managing change, and organizational practice;

Integrated curriculum that links all components of the preparation program around shared values and knowledge about effective practice;

University-community collaborations that facilitate consistency between theory and practice;

Field-based internships that engender application of knowledge and skills under the tutelage of experts;

Organizational arrangements that promote student retention, engagement, and future career placement;

Systematic processes that engender program and coursework evaluation and improvement;

Full-time tenure-track faculty that are actively engaged in promoting relevant knowledge on the essential challenges of leadership and teaching;

Low student-faculty ratio that is conjoined with active, student-centered instruction, and Professional development opportunities readily available to and eagerly embraced by faculty. 
While it is beyond the scope of this paper to discuss each of these features individually, we endeavor to highlight specific strategies used to engage students in relevant knowledge by means of active learning and the subsequent professional development of faculty and students that germinated via initial course requirements.

Theory Into Practice

As students in a doctoral program in educational administration, we had the good fortune of experiencing features of a high quality leadership preparation program in action (Young, et al., 2007). Moreover, we personally learned the import and value of integrating the development of legislative advocacy skills into educational leadership coursework. By utilizing coherent, research-based content and emphasizing active, collaborative learning groups, our professor, Dr. Michelle Young, modeled exemplary teaching and learning in educational leadership preparation programs, specifically, while teaching an educational policy analysis course. We were completely unaware during this formative stage that our research and trial projects would become the foundation for UCEA's new legislative advocacy program for educational administration practitioners and students.

First, students formed research teams with common interests to investigate a current state policy issue. The collaborative experienced first-hand how to divide the workload of a major research project and work effectively with peers. After commencing the research process, cooperative learning groups formed faux organizations to advocate or oppose a particular policy issue. The "organizations" then established an official purpose, goals, and vision then created corresponding pamphlets, mock websites, and professional development documents. Under the tutelage of Dr. Young, individuals and groups learned to translate their scholarly research into policy briefs to be shared with politicians and the public at large.

Thereafter, the newly-formed organizations investigated other major associations' legislative advocacy projects and practices. Based on the findings, each group fully planned simulated "Day on the Hill" experiences replete with guest speakers, catered food, and sample follow-up communications targeting legislators. Lastly, the projects were presented to peers and professors in a format similar to major organizations' conference venues such as AERA and UCEA.

The course concluded with our professor seeking volunteers to assist UCEA staff planning the inaugural "Day on the Hill" project in conjunction with UCEA's annual convention in Washington, DC, November, 2007. This move toward establishing an authentic "Day on the Hill" committee provided a true "ah-ha" moment for us as we at last realized the full import of our professor's syllabus aimed at preparing us for policy work outside academe.

\section{The Cross-generational Planning Committee}

A diverse group of approximately 15 people worked alongside one another to accomplish the goal of creating the "Day on the Hill" project. Professors and students, ranging in age from 20 to 60 , learned from each other the various components that serve as the foundation for such a huge undertaking. Based on interests and experiences, individuals worked together to facilitate various 
components of the project, such as creating professional development materials, making appointments with legislators and their aides, arranging meals and transportation, securing financial sponsors and guest speakers, and writing a policy brief and "talking points" for emphasis during advocacy visits.

The guiding principles undergirding the project were the purpose statements provided by Dr. Young and other UCEA leadership. All "Day on the Hill" activities would ultimately: (1) Promote understanding of the importance of quality leadership preparation to effective schools; (2) Emphasize the role that UCEA plays in supporting quality leadership preparation programs, and (3) Provide guidance on how legislators can support quality programs.

The "Day on the Hill” Experience

Participants arrived in Washington, DC prior to the start of the UCEA Convention. The day began with a continental breakfast and welcome by UCEA Executive Director, Michelle D. Young, who gave an overview of the UCEA Leadership Preparation Talking Points (Young, et al., 2007):

a) What do we know about the relationship between effective leadership, teacher quality, and student learning?

b) What do we know about how to prepare quality leaders?

c) What do we need to do to ensure further improvements in leadership preparation?

Next, participants rotated through three workshops led by Kathleen Brown, Gary Crow, Steve Gross, Catherine Lugg, Terry Orr, Diana Pounder, and Andrea Rorrer. The workshops were designed to cover the three talking points emphasized in the policy brief (Young, et al., 2007). Further, participants learned specific skills needed to conduct the visits, such as learning how to tell one's story powerfully and succinctly, keeping conversations focused on key points, and practicing how to elicit promises from legislators and their aides. We also discussed proper "Hill" etiquette and protocol for "drop-in" visits to legislators who were unable to establish firm appointments.

At the conclusion of the workshops, participants boarded a bus for Capitol Hill. We stopped at a bi-partisan professional lobbying company, 21 st Century Group, Inc., for a kick-off address delivered by company CEO, Jack Fields. We then visited the cafeteria located within the HouseSenate Complex where we ate our boxed lunches and finalized plans with the visitation groups. Approximately 40 students and professors conducted planned visits to 27 members of the House and Senate; representing 20 states. In addition to plentiful, informal "drop-ins" to additional legislators, UCEA members visited associates of the Department of Education, National Center for Education Statistics, and National Center for Education Research.

We concluded our day by partaking in a beautiful evening reception hosted by Cynthia Wilkinson, President of 21 st Century Group, Inc. at their DC headquarters. After enjoying delicious food and drink and gregarious sharing, we trickled back to our hotel via taxi or Metro.

Legislative Advocacy as Professional Growth 
Surveying "Day on the Hill" participants elicited a wide variety of intriguing responses. Eightysix-percent of participants had no prior experience with legislative advocacy on a national level, while $71 \%$ had no previous familiarity on the state level. Despite the fact that at least one-third noted they felt uninformed, nervous, or skeptical prior to the event, a majority of the group was excited about participating. As students, we were encouraged that the participants' sense of inadequacy or nervousness did not dissuade them from trying something new. Yet, we were still a bit worried about how people would feel after the event. Would people's feelings of inadequacy be reified? Would participants vow never to participate in future events?

Fortunately, 93\% of participants reported the "Day on the Hill" experience as a worthwhile learning experience that had a positive impact on the legislators they visited. Additionally, 100\% were convinced that UCEA should plan future "Hill" events on the national and state levels. Moreover, all participants reported they would participate in future visits to legislators in Washington, DC. Perhaps most importantly, two-thirds reported their willingness to help plan future state and national legislative advocacy projects.

Implications

Among today's oft-prescriptive policy environment, educational leaders are called to engage local, state, and federal policy constructs. The 2008 revised Interstate School Leaders Licensure Consortium (ISLLC) Standards heed this call by challenging leaders to take on educational policy in a more deliberative and purposeful fashion. Specifically, ISLLC Standard 6 requests educational leaders "promote the success of every student by understanding, responding to, and influencing the political, social, economic, legal and cultural context" (ISLLC Standards, 2008). In addition, Standard 6 states leaders should: a) advocate for children, families, and caregivers; b) act to influence local, district, state, and national decisions affecting student learning, and c) assess, analyze, and anticipate emerging trends and initiatives in order to adapt leadership strategies (ISLLC Standards, 2008).

Recall, before UCEA's Day on the Hill activity, an overwhelming number of active UCEA scholars had no prior experience with advocacy efforts at the state or federal level. The same participants, who are considered able and vocal education advocates by their colleagues, identified themselves as nervous, skeptical, and without previous knowledge of formal legislative advocacy. We believe that the Council of Chief State School Officers (CCSSO), by embedding within the new ISSLLC Standards a purposeful nudge towards participatory engagement, addressed an urgent need for able and vocal advocates to become participatory partners in the state and federal policymaking. The foresight of UCEA, CCSSO, and professors such as Dr. Michelle Young, deliberately confront the constraining environment that educators now often find themselves working within. By becoming meaningful partners in the policy creation phase, educators can influence the policy agenda rather than merely responding to an agenda that educators often perceive as intrusive and insensitive to local needs and desires. Instead of reacting to policies defined solely by persons at the state and federal level, activities such as the UCEA "Day on the Hill" and guidelines such as the 2008 ISLLC Standards encourage a collaborative forum where diverse needs are defined in a deliberative manner. 


\section{Conclusion}

Whether a rural, suburban, or urban school district, today's schools are distinct and dynamic environments, each owning their own set of contextually unique set of challenges, obstacles, strengths, and weaknesses. Our society can ill afford to continue distributing universal policies without the meaningful input of all educational leaders. This being said, within our own UCEA activity, the small sample group of "Day on the Hill" participants implies many educators are not adequately prepared or are not encouraged to participate in policy making at the state or national levels. This is a troubling finding and one that must be addressed with immediacy by the institutions called to prepare the next generation of educational leaders.

Dr. Young's recommendations noted herein should be recognized as a purposeful and successful effort towards the preparation of active and engaged leaders. By challenging current scholars and students to guide federal legislators regarding urgent needs for high-quality leadership programs, and by educating federal policymakers about the critical role UCEA can and will play in supporting high-quality leadership preparation institutions, the scholars took the first and most instrumental steps toward creating a future for educational leaders which promises to be engaged, participatory, and relevant.

For the doctoral students involved, a major highlight of committee membership included meeting and working with researchers whose scholarship we had read during our doctoral coursework. Moreover, being a part of a project from our professor's inception to its fruition was enormously satisfying. There was a strong sense among committee members that we were involved in important work that had the potential to significantly impact schools and the children they serve. As is the case with many learning endeavors, the final products were not nearly as critical as the scholarly capacity gained during the creation phase of the project. Intense interaction with highly regarded scholarship, while learning to advocate for high quality leadership preparation through meaningful interaction with those responsible for setting and revising the educational policy, made the experiences in this course a critical touchstone event for the budding scholars involved.

The next steps for UCEA include making "Day on the Hill" at the national level a regular part of UCEA's advocacy efforts. In addition, members of UCEA institutions in Texas have met to explore the development of an advocacy coalition to promote educational best practices to the Texas Legislature. Of particular interest is supporting the need for high-quality data collection systems that will aid legislators and educators in sound decision-making.

\section{References}

Darling-Hammond, L., LaPointe, M., Meyerson, D., Orr. M. T., \& Cohen, C. (2007). Preparing School Leaders for a Changing World: Lessons from Exemplary Leadership Development Programs. Stanford, CA: Stanford University, Stanford Educational Leadership Institute.

Davis, S., Darling Hammond, L., Meyerson, D., \& LaPointe, M. (2005). Review of research. School leadership study. Developing successful principals. Palo Alto, CA: Stanford University, Stanford Educational Leadership Institute. 
Fuller, E., Orr, M. T., \& Young, M. D. (2008, March). Implications from UCEA: The Revolving Door of the Principalship. http://www.ucea.org

ISLLC Standards. (2008). Retrieved April 20, 2008, from http://www.ccsso.org/projects/education_leadership_initiatives/ISLLC_Standards/

Jackson, B. L., \& Kelley, C. (2002). Exceptional and innovative programs in educational leadership. Educational Administration Quarterly, 38(2), 192-212.

Orr, M. T. (2007, April). How preparation impacts school leaders and their school improvement: Comparing exemplary and conventionally prepared principals. Paper presented at the annual meeting of the American Educational Research Association, Chicago, IL.

Orr, M. T. \& Orphanos, S. (2007, April). Learning leadership matters: Teachers' experiences of innovatively and conventionally prepared principals. Paper presented at the annual meeting of the American Educational Research Association, Chicago, IL.

Peterson, K. D., \& Finn, C. E. (1985). Principals, superintendents, and administrator's art. The Public Interest, 79, 42-62.

U. S. Department of Education.(2005). FY 2005 School Leadership Application for Grants. DC: U. S. Department of Education, Office of Innovation and Improvement.

Young, M.D., Fuller, E., Brewer, C., Carpenter, B., \& Mansfield, K.C. (2007). Quality Leadership Matters. UCEA Policy Brief Series, 1(1),1-8, from http://www.ucea.org/

Katherine Cumings Mansfield is a third-year doctoral student in Educational Policy and Planning at University of Texas at Austin. She pursues additional credentials in Women's and Gender Studies from the College of Liberal Arts and Public Policy Dispute Resolution and Mediation from the School of Law. Mansfield's scholarship focuses on the politics of education and the relationship of gender, race, religion, and class on educational and vocational access and achievement. In addition to JRLE, Mansfield is published in Intersections: Women's and Gender Studies in Review across Disciplines; Encyclopedia of Gender and Society, and UCEA Review. Mansfield has presented at AERA and UCEA and is scheduled to present at the National Summit on Interdistrict Desegregation at Harvard Law School in January and Legal and Policy Options for Racially Integrated Education in the South at UNC-Chapel Hill Law School in April.

Bradley W. Carpenter is a third year doctoral student in Educational Policy \& Planning at University of Texas at Austin. He works as a graduate research assistant to Dr. Michelle Young and the University Council for Educational Administration. Carpenter serves as President of The University of Texas Graduate Student Assembly and is co-chair of the Department of Educational Administration's P-20 committee. Carpenter's scholarship focuses on the critical interrogation of education policies that directly impact educational leaders and their abilities to create an educational environment that is both equitable and rewarding for students, teachers, 
and communities. His work is published in the Encyclopedia of Educational Law, Journal of School Public Relations, and UCEA Review. Carpenter has presented at AERA, UCEA, and Temple University's NEW DEEL Conference. Current projects include working with UCEA on the Urban Principalship Curriculum Development Project. 